\title{
Population of yew tree Taxus baccata L. in Latvia
}

\author{
Ināra Bondare \\ National Botanical Garden, \\ 1, Miera Street, \\ Salaspils, \\ LV-2169, Latvia
}

Common yew (Taxus baccata $\mathrm{L}$.) is a rare and endangered species included in Red Data Book of Latvia. The species grows on the eastern edge of its distribution area. It is mainly found in the SW parts of Kurland near the Baltic Sea coast and the Gulf of Riga (in some localities). Most yew are understory plants and grow well in the shade in a climatic zone with soft winters and cool summers. As this conifer has high landscape value and is relict since atlantic times it needs protection. In Kurland restricted area "Rucavas ivju audze" ("Yew grove of Rucava") was established which is situated in the SW of the maritime territory in the Bārtavas lowland - 206 ha area. The biggest common yew tree $(14 \mathrm{~m})$ grows in park Zentene (in the district of Tukums). It is an open question whether artificial propagation of naturally growing plants in situ with consequent re-cultivation in situ could be considered a natural process of the species preservation.

This paper also presents a collection of yew taxa which have been planted in the Arboretum of Rucava in the period of 15 years.

Key words: Taxus baccata, Latvia, distribution, conservation, propagation

\section{INTRODUCTION}

Yew tree population covers Western Europe, Baltic States, Crimea, Caucasus, and Northwestern Africa (Farjon, 1999). In the Latvian wild yew family (Taxaceae Gray), which includes five genera, is represented by a single genus of one species - Taxus baccata L. Species name is derived from a Latin word "bacca" which means "berry,

* Corresponding author. E-mail: inbon@inbox.lv pearl". Baltics is the NE distribution border of the yew tree species and is rarely found, mainly on the west seaside. It is expected that yew tree had already grown in Latvia (Fig. 1) during the interglacial age with a much wider range than before. Presently it is included in the list of protected plants of Latvia - Sarkanā grāmata, Red Data Book (Cinovskis, 2003).

Society raises the question of whether artificial propagation should be done at all. 


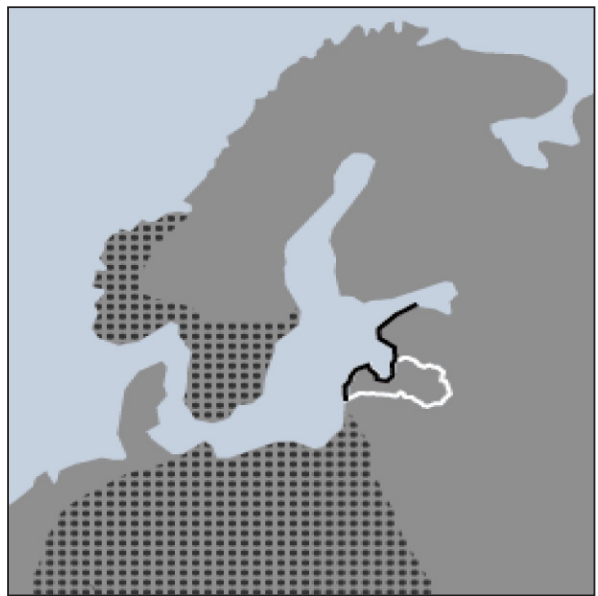

Fig. 1. Common yew (Taxus baccata L.) distribution in Latvia and North Europe (www.latvijasdaba.lv/ augi/taxus-baccata-1/)

\section{MATERIALS AND METHODS}

The inventory of indigenous tree and shrub species in the Kurland region was carried out in 1991-2000, in total on 402 sites, such as urban and rural parks, cemetries, forests, roadsides, private collections. In the list of taxa there are indications as to the number of specimens, and the dimensions for the biggest specimens of common yew (Bice et al., 2003). The next inventory and documentation of ecological situation was carried out in 2010-2013.

\section{RESULTS AND DISCUSSION}

It is difficult to tell whether 1000 yew tree variations in our republic is a lot or not. Distribution area of the yew tree reminds a long woven ribbon along the Gulf of Riga and the Baltic Sea coastline and stretches $500 \mathrm{~km}$ and is $10 \mathrm{~km}$ wide. It has been thought that the yew range in Latvia could be as large as $5000 \mathrm{~km}^{2}$ and on average the distribution of yew trees is one tree by $3 \mathrm{~km}^{2}$.

Since the yew is a dioecious plant, the nature is wise and placed them evenly throughout the territory, but the concentration is rather single to the successful development of the population - concentrated in the same isle-type suitable growth areas. Data show that of the eight districts of Latvian indigenous origin yew trees are found only in two districts - seaside land (84\%) and Kurzemes highlands (16\%). Much of the yew tree population can be found at Sliteru reservation, Nica and Rucava forestry. In this place they are found $0.75 \%$, i. e. 1250 ha of forest area has one yew tree (Riekstiņš, 1981).

The maximum height a yew tree has reached in Latvia is $14 \mathrm{~m}$, the biggest is at Tukuma region, park Zentene (Fig. 2).

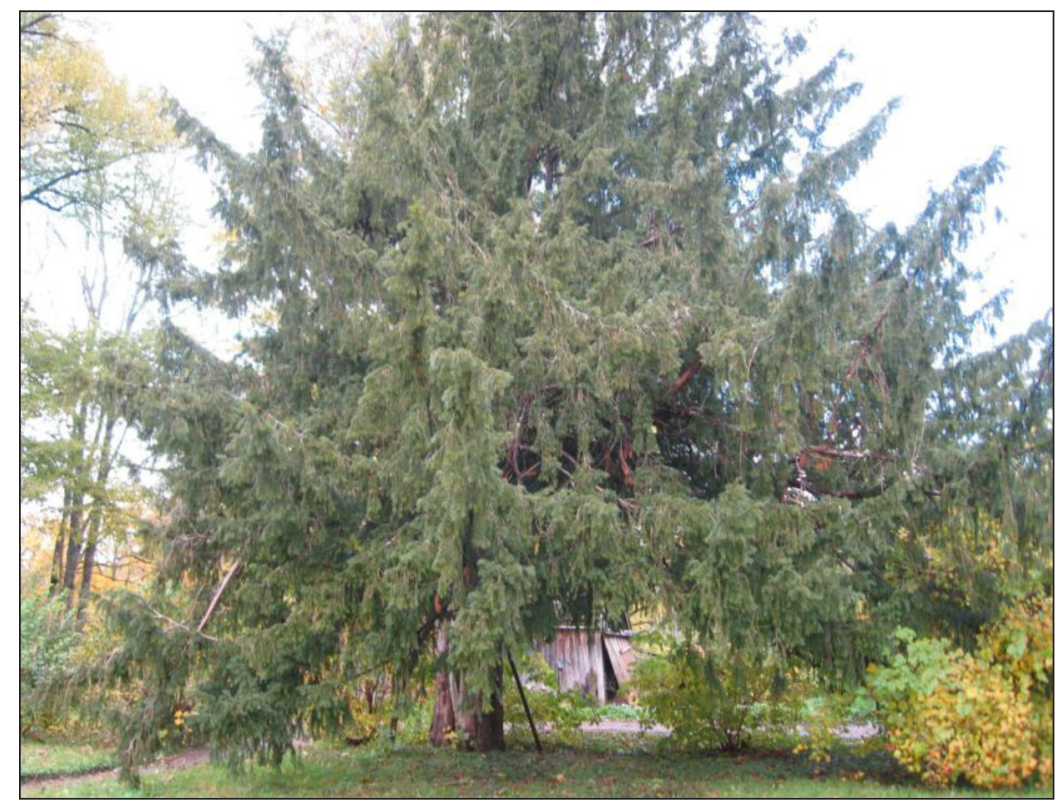

Fig. 2. Common yew in park Zentene 


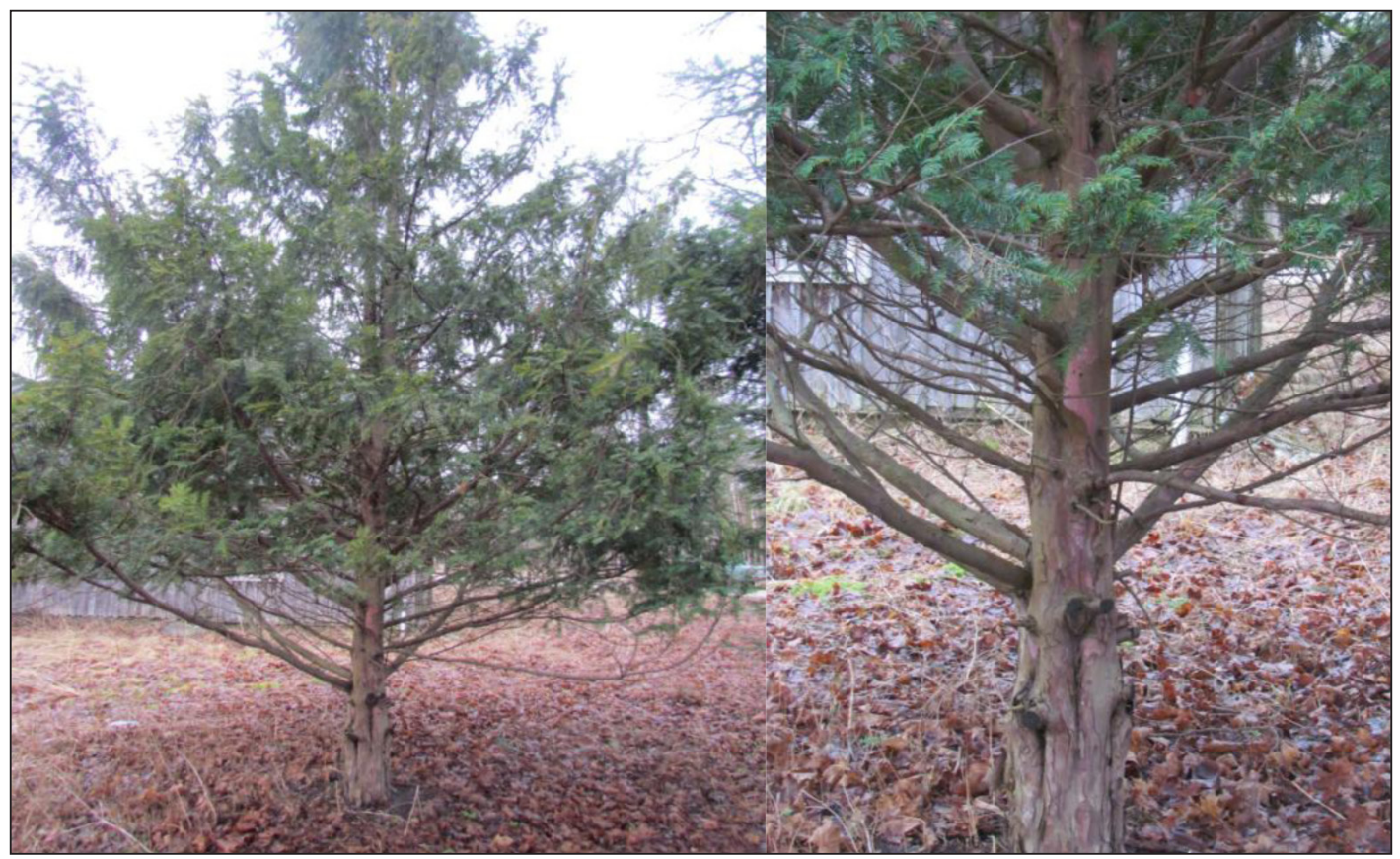

Figs. 3-4. Common yew in Kalniski, Rucava region, January, 2013

$8 \mathrm{~m}$ old yew trees can be found in Kalniski, Rucava region. 8-10 specimens found in 2013 (Figs. 3 and 4).

Depending on the growing conditions, they form a tree or a shrub (Fig. 5).

The form diversity is not an end in itself but is regulated by survival. For a yew tree optimal climate conditions are in the regions with mild winter and cool summer, where average January temperature is $-3-3.5^{\circ} \mathrm{C}$. Species excels in calcareous soils, i.e. it can grow from dry to wet, weak acid or weak bases and humus-rich soils (Riekstiņš, 1986). Yew tree is typical broadleaved forest tree species in the second floor. As yew can achieve considerable age, the cutting down of broad-leaved forest trees on the ground floor may lead to a pure stand of yew trees, and these pure stands are found in Europe. A pure

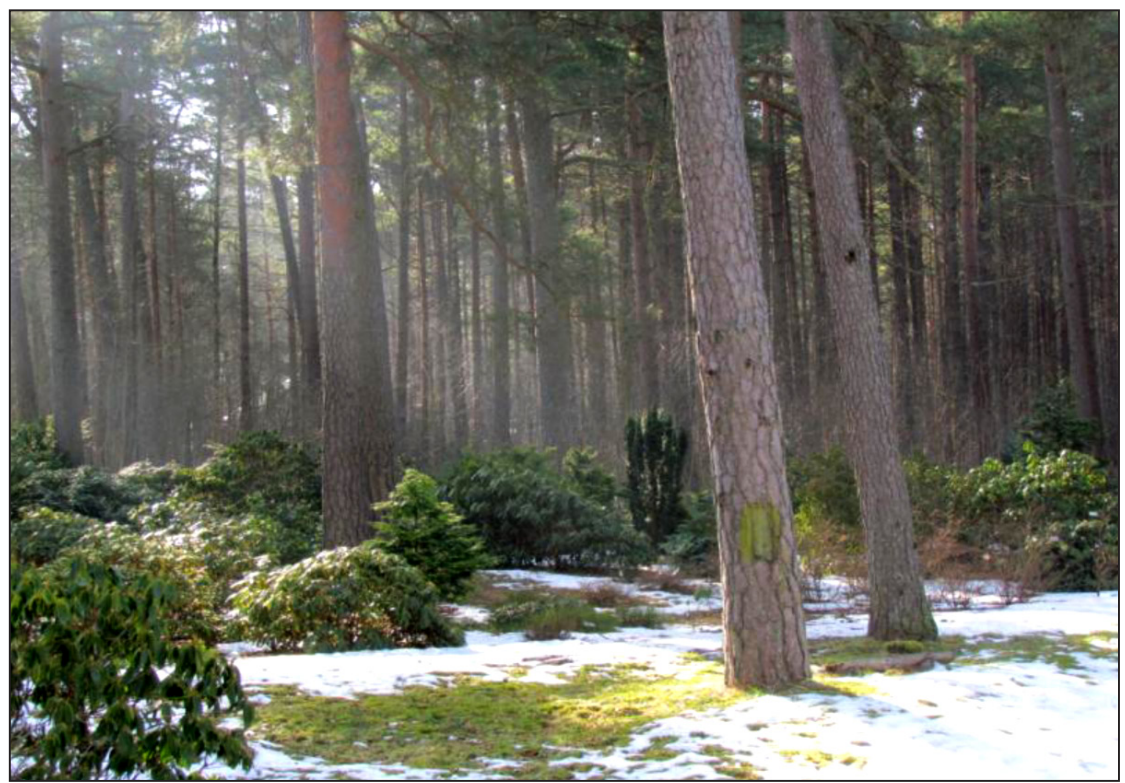

Fig. 5. Common yew - shrub forms (cv) in forests of Rucava 


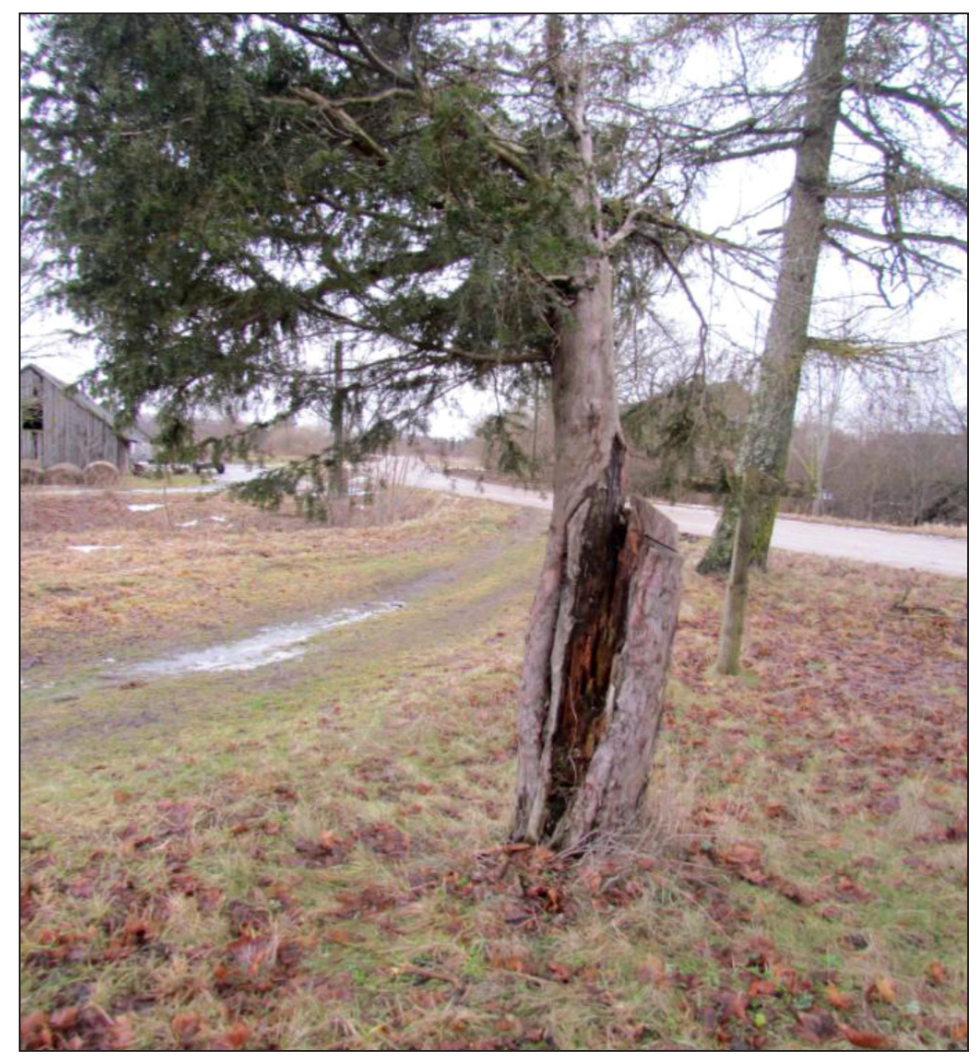

Fig. 6. Damaging trunks of a common yew

stand where the yew tree crown forms a very frequent branching it creates a shadow that affects the development of other plants. Usually during deforestation and development time, ruthless use of modern techniques destroys yew tree population. Hovwever, the population at the forest edge severely suffers from human activities, namely breaking branches and damaging trunks (Fig. 6).

Also, it cannot go unmentioned that in several European countries, including Lithuania, yew trees were extensively used in witchcraft, of course due to the toxicity of the tree (alkaloids are toxins). It is a fact that chemicals of this group are dangerous in certain doses, but using them reasonably they can be used as medicine both for animals and humans. During winter wild animals (roe deer) nibble on yew trees thus destroying helminth in the intestine. Wild animals use yew trees in a reasonable dose. Due to these toxins farmers sometimes cut down yew trees to protect their livestock. In any case, wildlife damage inflicted upon yew trees cannot be compared to the damage done deliberately by people (Dempsey, 2003; Farjon, 2008).

The myth that yew trees can only grow in shade is incorrect. They can also grow in protected areas in full sunlight. The fact is that yew trees tolerate large shadows but when there is a tight space for its growth they wither away and may die. The ideal place for yew tree development is a forest stand with a partial sunlight.

Yew tree is a dioecious plant with female and male specimens and to have a possibility of pollination the maximum distance from each other is $100 \mathrm{~m}$. Unfortunately, there also are other obstacles in the forest. Birds are the only distributers of yew tree berries. The belief that a new yew tree may not be planted under older yew trees is false and misleading (Fig. 7).

Under conditions of partial shading, the new specimens germinate abundantly. It is common for yew trees to have "endotrophic mycorrhiza", mycorrhiza hypha is located between cells and also in the cells. It is possible that the inner mycorrhiza stimulates and eases 


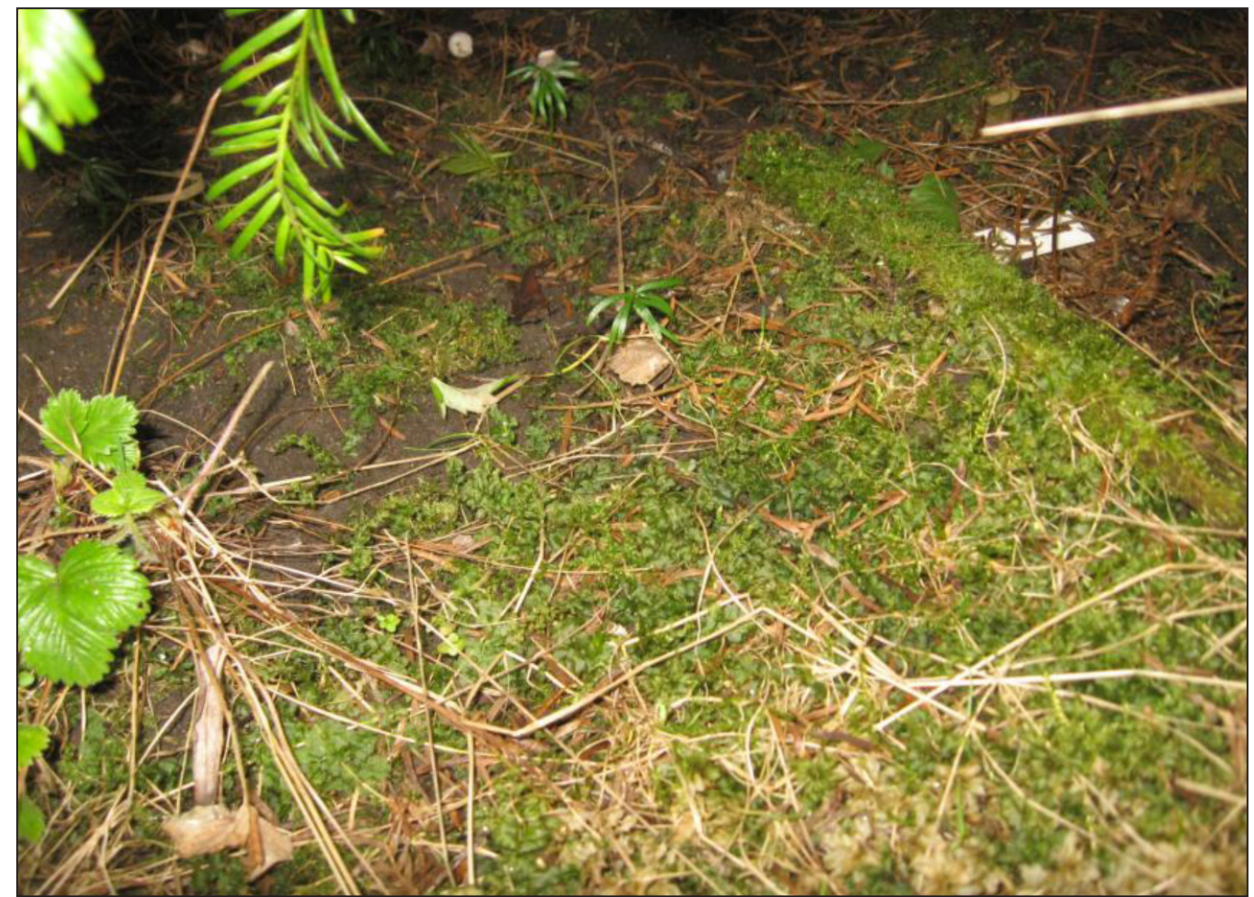

Fig. 7. Seedling of common yew

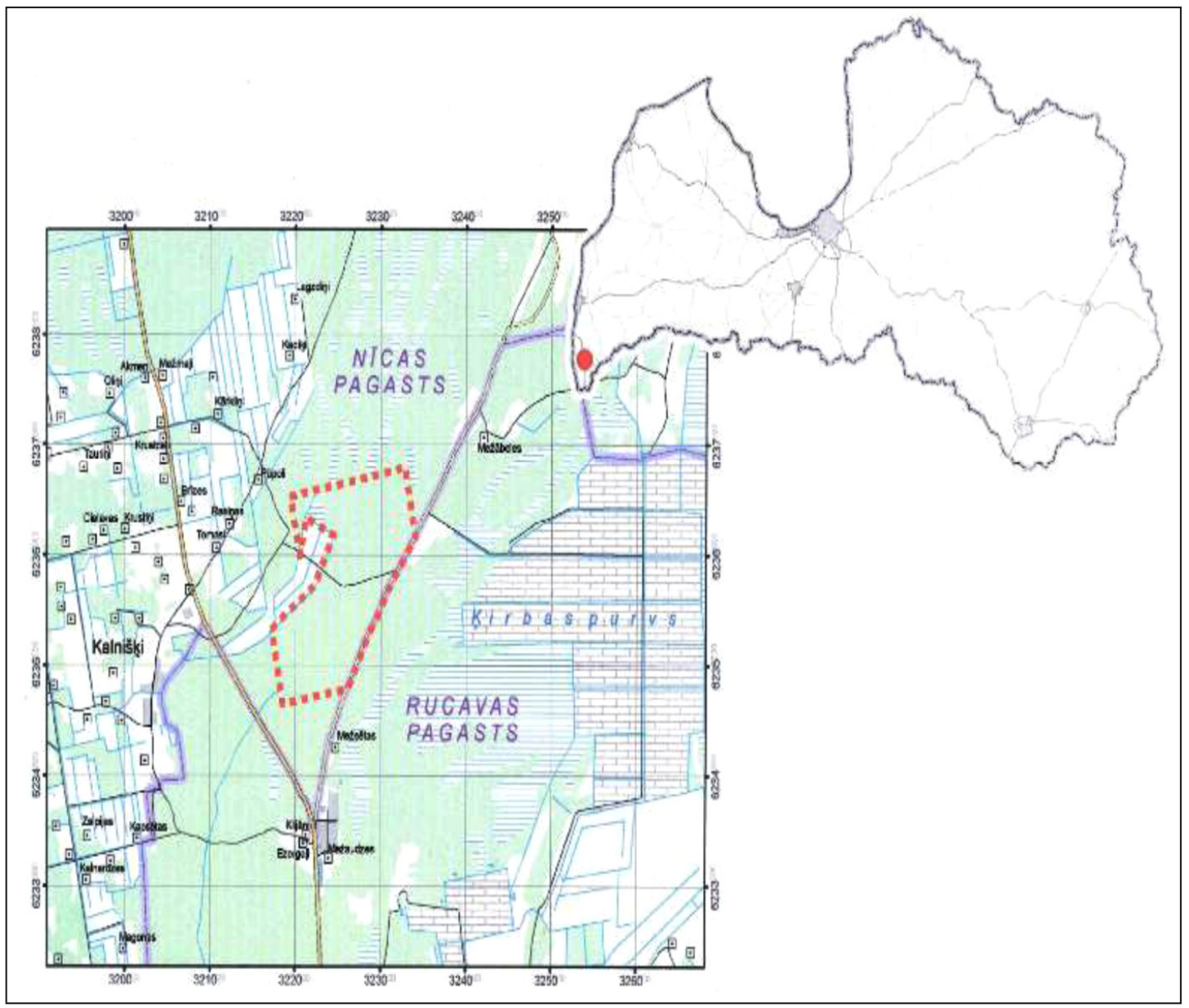

Fig. 8. Nature preserve - "Rucavas ivju audze" 
yew tree growing into the specific site (Farjon, 1999). This factor is important for vegetative reproduction of yew cuttings; it germinates better if rooted cuttings are replanted in the substrate where a suitable forest soil is added. In this case, the fungi serve the purpose of helping the plant to easier absorb nutrients from soil minerals in organic matter. In the higher plant community yew trees have many friends (Bondare et al., 2000). In Europe, they are often found in the orchid, beech and hornbeam forests. In Latvia individual trees or their small groups are usually found in the mixed spruce forests as well as moist spruce forests, rich deciduous forests (Riekstiņš, 1986).

Yew propagation with collected wild material dates from the last century Latvian 80th years to enhance reintroduction in the ecosystem. The first to begin this was the Dundagas forestry. During the period 19821985 yew trees were propagated with cuttings (Riekstiņš, 1980) planted at the Slitere Nature Reserve (1 000 pcs.). In later years another 1000 pcs. were added. Unfortunately, there are no up-to-date monitoring of these plantations therefore the current state of the yew trees is unknown.

In recent years, a new Latvian Nature Reserve - "Rucavas ivju audze" (Fig. 8) marked on site, where from 2005 until 2015 will the yew tree population is being observed (Salmiņa, 2005).

\section{CONCLUSIONS}

Forming the first artificial plantations experts came to a conclusion that yew artificial propagation and back to the forest is the only way for this species to persist in Latvia. Due to varied human economic activities sparsely leaved forests, which are optimal for species habitat, disappeared.

Received 22 July 2013 Accepted 15 September 2013

\section{References}

1. Bice M, Knape Dz, Šmite D, Bondare I. Trees and shrubs of the Liepaja region. Latvijas Veǵetācija, Rīga, LU izdevniecība, 2003, 6: 74 (in Latvian).

2. Bondare I, Zaķìte S. Research of lignin-silicon preparations effects of common Yew (Taxus baccata L.) and northern white cedar (Thuja occidentalis L.) in the cutting rooting process. Baltic Botanic Gardens. 2000, 29-35.

3. Cinovskis R. Taxus baccata L. Red Data Book of Latvia (ed.) G. Andrušaitis. Rīga: LU Bioloǵijas institūts, 2003, 3: 84-85.

4. Dempsey D, O'Flaherty C, Hook I. Taxus species. Morphological and Chemical Variations in Needles and Seeds. Proceedings of the Fourth International Conifer Conference 2008. Bruge: Drukkerij Van Damme-Beke, 2003, 223-228.

5. Farjon A. A natural history of conifers. Oregon: Timber Press, 2008, 238-239.

6. Farjon A. Conifers. Cambridge: UCN, 1999, 5.

7. Riekstiņš I. Ogu ìves pavairošana ar spraudeņiem. Mežsaimniecība un mežrūpniecība. 1980, 1: 35-40 (in Latvian).

8. Riekstiņš I., Aizsargājamās teritorijas un to loma ogu ìves genofonda saglabāšanā. Mežsaimniecība un mežrūpniecība - 1981, 3: 2427.

9. Riekstinš̌ I., Īve- piejūras meža pērle. Rīga, Zinātne, 1986, 76.

10. Salmina L. Dabas lieguma "Rucavas ivju audze” dabas lieguma plāns. Rīga, 2005, 10 (in Latvian).

\section{Ināra Bondare}

\section{EUROPINIO KUKMEDŽIO TAXUS BACCATA L. POPULIACIJA LATVIJOJE}

Santrauka

Europinis kukmedis (Taxus baccata L.) yra reta ir nykstanti rūšis, ịtraukta ị Latvijos Raudonąą knygą ir aptinkama rytiniame Latvijos regione. Šiu 
medžių randama Kurlando pietvakarinèje dalyje šalia Baltijos jūros paplūdimio ir Rygos illankoje. Kukmedžiai gerai auga šešèlyje, jiems tinka tos klimato zonos, kuriose vyrauja švelnios žiemos ir šaltesnès vasaros. Kadangi šie augalai pasižymi aukšta kraštovaizdžio verte ir yra Atlanto laikų reliktas, jiems reikalinga apsauga. Tam tikslui Kurlande issteigta „Rucavas ivju audze“ (Rukavos kukmedžių giraitè), išsidèsčiusi pietvakarių žemumoje, Bārtavos teritorijoje 206 ha plote. Didžiausias europinis kukmedis auga Zentenes parke (Tukums rajone). Vis dar diskutuotinas lieka klausimas, ar reikia propaguoti natūralų augalų auginimą ex situ ar kultivavimą in situ. Šiame straipsnyje pristatoma europinio kukmedžio kolekcija, kuri buvo surinkta per 15 metų Rukavos medelyne.

Raktažodžiai: Taxus baccata, Latvija, paplitimas, saugojimas, dauginimas 